\title{
THE DEVELOPMENT OF PANTIKU APPLICATION BUSINESS STRATEGY USING BUSINESS MODEL CANVAS APPROACH
}

\author{
Sari Wulandari ${ }^{*}$, , Meldi Rendra*), Putra Fajar Alam ${ }^{* *}$, Tien Fabrianti Kusumasari ${ }^{* *}$, Andrieta \\ Shintia Dewi ${ }^{* * *}$, and Tieka Trikartika Gustyana $\left.{ }^{* * *}\right)$ \\ *) Industrial Engineering Department, School of Industrial and System Engineering, Telkom University \\ Jl. Telekomunikasi No.1, Terusan Buah Batu, Bandung, 40257 \\ **) Information System Department, School of Industrial and System Engineering, Telkom University \\ Jl. Telekomunikasi No.1, Terusan Buah Batu, Bandung, 40257 \\ ${ }^{* * *}$ Management of Business in Telecommunications and Informatics Department, School of Economic and Business, \\ Telkom University \\ Jl. Telekomunikasi No.1, Terusan Buah Batu, Bandung, 40257
}

\begin{abstract}
Based on data from the Ministry of Social Affairs, there are 7,000 more orphanages in Indonesia and 500-600 thousand people are living in the orphanage. To make efficient operational activities and monitoring activities of the orphanage and to facilitate the provision of assistance, the orphanage uses the PantiKu application. The PantiKu application currently does not have an optimal business model so that the right strategy is needed to develop the business model. The objectives of this study are (1) To map the current PantiKu business model; (2) Analyze SWOT of current PantiKu business model; (3) Formulate and determine the strategy for developing the PantiKu business model. The method used in this study is the Business Model Canvas approach and SWOT Analysis. This research produces strategies for each BMC element including element (1) customer segment: serving orphanage volunteers by adding special volunteer features; (2) value proposition: providing ease of logistics processes and transactions by developing IoT technology and Fintech features; (3) channels: adding application tutorials using e-learning; (4) customer relationship: take advantage of opportunities for grants and business incubation and work together in CSR programs; (5) revenue stream: utilizing the use of digital financial instruments; (6) key resources: adding relationship development staff; (7) key activities: developing a data management dashboard and evaluate expenses; (8) key partners: adding strategic partner \& collaborate with competitors; (9) cost structure: cost of research.
\end{abstract}

Keywords: pantiku, business model, business strategy, BMC, application development

\begin{abstract}
Abstrak: Berdasarkan data Kementerian Sosial terdapat 7.000 lebih Panti Asuhan di Indonesia dan terdapat 500-600 ribu jiwa menempati Panti Asuhan tersebut. Dalam upaya melakukan efisiensi kegiatan operasional dan kegiatan pengawasan panti serta untuk memudahkan pemberian bantuan, Panti Asuhan menggunakan aplikasi PantiKu. Aplikasi PantiKu saat ini belum memiliki model bisnis yang optimal sehingga diperlukan strategi yang tepat untuk mengembangkan model bisnis tersebut. Adapun tujuan dari penelitian ini adalah (1) Memetakan model bisnis PantiKu saat ini; (2) Menganalisis SWOT model bisnis PantiKu saat ini; (3) Merumuskan dan menentukan strategi pengembangan model bisnis PantiKu. Metode yang digunakan dalam penelitian ini adalah pendekatan Business Model Canvas dan Analisis SWOT. Penelitian ini menghasilkan strategi untuk setiap elemen BMC diantaranya adalah: elemen (1) customer segment: melayani relawan Panti Asuhan dengan menambahkan fitur khusus relawan; (2) value propotion: memberikan kemudahan proses logistik dan transaksi dengan memgembangkan teknologi IoT dan fitur Fintech; (3) channels: menambahkan tutorial aplikasi menggunakan e-learning; (4) customer relationship: memanfaatkan peluang dana hibah dan inkubasi bisnis serta bekerja sama dalam program CSR; (5) revenue stream: memanfaatkan penggunaan instrument keuangan digital; (6) key resources: menambahkan staf relationship development; (7) key activities: mengembangkan dashboard pengelolaan data dan mengevaluasi pengeluaran; (8) key partners: menambahkan partner strategis \& kolaborasi dengan competitor; (9) cost structure: biaya riset.
\end{abstract}

Kata kunci: pantiku, model bisnis, strategi bisnis, BMC, pengembangan aplikasi

\footnotetext{
${ }^{1}$ Corresponding author:

Email: sariwulandariit@telkomuniversity.ac.id
} 


\section{INTRODUCTION}

According to the Ministry of Social Affairs of the Republic of Indonesia, orphanages have at least 3 functions including (1) As a social welfare service center for child, (2) As a center for data and information and consultation on children's social welfare and (3) As a center for skill development (which is a supporting function). orphanages have voluntary caregivers who replace the role of parents in caring for and providing guidance to neglected children who are entrusted and accommodated by the orphanage. The neglected children are entrusted because of various factors such as a low family economic condition so that parents cannot afford to pay for their children and children who do not have parents or orphans. In 2017, there were 44 million poor children and 4.1 million neglected children in Indonesia (Manafe \& Evani, 2017). Therefore, the role of orphanage is very strategic for Indonesia. Also, the daily social activities of the orphanage are carried out using donations or social funds originating from various sources such as government, community, and foundation funds. The higher the number of children accommodated, the greater the funding needs. At present, Indonesia has 7,000 orphanage units that need to be funded (Kuswandi, 2018) while distributing funds there are still many constraints including the incompatibility of funds with the needs of the orphanage so that funds or assistance provided are often not on target.

The use of information technology can be used as a solution which is by providing an information system in the form of a mobile application that can provide access to information about the needs of the orphanage and facilitate donors in providing funds and aid. Besides, PantiKu Application also connects all stakeholders such as orphanages, Social Services, and Communities (as donors) so that good communication can be established among stakeholders. In terms of technology acceptance, the use of applications as a daily activity media also faces some constraints that are the orphanage administrators not used to using apps and adjusting application features to user's needs. This research was conducted to design a business development strategy for PantiKu application using the Business Model Canvas approach.

Business Model Canvas (BMC) is one of the approaches used to design business models by changing complex business concepts to be easier to understand (Nurhakim;
Suparno, Nurrochmat, 2018). BMC consists of nine structured elements that represent business content run by a company (Keane, Cormican, \& Sheahan, 2018). Osterwalder (2004) explains that the nine elements in BMC are part of a four-dimensional concept of business model, namely product aspects, customer interface aspects, infrastructure management aspects, and financial aspects (Keane et al. 2018). The mapping results of the PantiKu business model then used as consideration in developing the PantiKu business strategy. Furthermore, in this research, a SWOT analysis of nine BMC blocks was also carried out to find out the development of the PantiKu business model for the future.

This study also conducted a literature study of previous research. The results of the literature study used as references for doing this research. Kadir (2018) in his study, developed a business strategy for silk weaving businesses in the Wajo Regency, South Sulawesi Province. The findings in the study are that BMC is a canvas approach that can simplify complex business models to facilitate entrepreneurs in identifying business potential. The use of BMC as an approach in developing business was also carried out by Prasetyo, Baga, \& Yuliati (2018) in their research entitled Business Development Strategy Rhythm of Empowerment (ROE). In addition to using BMC, ROE business model develops using SWOT analysis. Furthermore, León et al (2016) also uses BMC as a research method. León et al. (2016) developed a digital ecosystem model for healthcare and wellness by utilizing the BMC approach. On the other hand, Gabriel \& Kirkwood (2016) uses the BMC approach to map and analyze business models of renewable energy entrepreneurs in 28 developing countries.

Development of business models by using BMC is also carried out on digital-based businesses. Cherif \& Grant (2014) in their research analyze the e-business model of seven digital company. Cherif \& Grant (2014) evaluated the similarities and differences of each e-business model and analyzed how the e-business model had an impact on the company's success. Similar research was also conducted by Ju et al. (2016). Ju et al. (2016) saw that Internet of Things (IoT) opens new business opportunities by connecting physical objects with multiple sensors so that it is necessary to develop a generic business model framework for IoT businesses. The findings from the results of the literature analysis ( $\mathrm{Ju}$ et al. 2016) include some previous studies using BMC 
as an approach in developing business models as done by (Sun, Yan, Lu, Bie, \& Thomas, 2012), (Bucherer \& Uckelmann, 2011), and (Dijkman, Sprenkels, Peeters, \& Janssen, 2015), while other business model approaches used are MOP Model and Value Net Model. Research on the analysis of the IoT technology business service operating business model using BMC is also carried out by Díaz-Díaz, Muñoz, \& Pérez-González (2017). In their research found that integrated public services using IoT technology can reduce costs in the long run. Besides, from the analysis of the public service business model using IoT technology, it is known that the use of IoT technology can reduce the energy consumption and environmental impact of the consequent social impact. The research is similar to Díaz-Díaz, Muñoz, \& Pérez-González (2017) which is an analysis of the IoT technology business model using the BMC approach, but in the healthcare sector, it is also done by Nguyen Dang Tuan et al. (2019). In their research, it was found that IoT technology can improve healthcare organizations business models to achieve low-cost services.

The use of BMC has also expanded in the fields of government and social enterprises as practiced by Martins et al. (2019), Canestrino et al. (2019), and Joyce \& Paquin (2016). Martins et al. (2019) in his research developed the ontology of public governance using the canvas business model approach (Sparviero, 2019) developing the Social Enterprise Model Canvas (SEMC) model as an alternative to the use of BMC in social companies. Canestrino et al. (2019) adapted BMC and produced a Canvas Social Model (SBM) in identifying key factors for creating social value. SBM canvas can then be used for social enterprise. Joyce \& Paquin (2016) use the tripled layered Business Model Canvas as a tool to explore sustainabilityoriented business innovation models by adding two layers: environmental layers based on the perspective of the lifecycle and social layer based on stakeholder perspectives.

At present, Fintech business growth is very rapid at $24.6 \%$ from the previous year. On the other hand, the development of Fintech business has entered various sectors, starting from startup payments, financing, financial planning, and others. The number of Fintech service users per year is 135-140 companies (Ardela, 2017). PantiKu is one of the Fintech applications to facilitate the donation and financial operations of the orphanage. Based on the results of the literature study, it can be concluded that the scientific contribution provided through this research is to fill the research gap regarding the analysis and development of fintech technology social application business models.

The purpose of this study is to develop a business model for PantiKu application using the canvas model business approach and SWOT Analysis. In order to develop the PantiKu application business model, the objectives of this study are (1) Mapping the current PantiKu business model; (2) Analyze SWOT of current PantiKu model; (3) Formulate and determine the strategy for developing the PantiKu business model.

\section{METHODS}

This research is the result of community service of schemes in the internal collaboration of Telkom University carried out across scientific study programs in Industrial Engineering, Information Systems, and Business Accounting. The research was conducted for six months starting with the identification of user's needs (orphanage managers, donors, and social services), literature studies, proposal preparation, application design, and data collection at the orphanage. The orphanage that is as a companion application is Kurnia Asih orphanage located in Pasir Luyu Raya, Bandung. This research was conducted on December 20th, 2018. Kurnia Asih orphanage has 33 foster children with 13 caregivers who work voluntarily.

The design of PantiKu business model uses primary data and secondary data. Primary data was obtained through interviews and focus group discussions with caregivers, donors, and application developers while secondary data used the data from Kurnia Asih orphanage documentation. The data collection techniques used in this study are: Observation (direct observation of field conditions), namely to understand the business process of fund management and logistics of the orphanage. Interviews and Focus Group Discussions (FGD) to identify user's needs and also identify application development opportunities.

The data obtained was then processed and analyzed using descriptive analysis techniques describing and mapping nine elements of the canvas model business based on data and SWOT analysis of nine elements of 
the canvas model business. The results of the business model mapping and SWOT analysis then used as the basis for consideration in formulating the business strategy for developing PantiKu application.

The respondents in this study consist of three groups of respondents, namely caregivers (Foster workers $=3$ respondents), donors of institutions (Orphanage donors $=4$ respondents), and application developers ( 3 respondents). Respondents in foster care provide data and information about the business process of fund management and nursing logistics while the donors of institution provide data and information about the problems and needs of the donation function.

The next step, essential factor identification in each BMC element was conducted using the data obtained. The subsequent process is to analyze the SWOT of each element of the canvas model business. The results of SWOT analysis of nine BMC elements are the basis for consideration in formulating the business strategy for developing PantiKu application. After carrying out a SWOT analysis on each BMC element, the next process is to map the results of the SWOT analysis in the SWOT matrix so that a business model development strategy can be determined that is under the conditions for the application of the PantiKu. The description of the research framework can be seen in Figure 1.

\section{RESULTS}

\section{Mapping of Business Model}

The mapping process of preparing PantiKu strategy is conducted using FGD. This process aims to identify nine BMC elements. The results of interviews then grouped into nine BMC elements and then illustrated in Figure 2.

\section{Analysis of PantiKu BMC}

This study involved the entire research team of PantiKu application which acted as a resource person to provide an overview of the BMC compiled. Data retrieval in this study was conducted by FGD with research team (application developer), orphanage managers, and donors. This review was performed because the discussion participants are stakeholders in the concept of the application for PantiKu and can provide comprehensive insight because they are the perpetrators of daily activities in the social field, especially the orphanage.

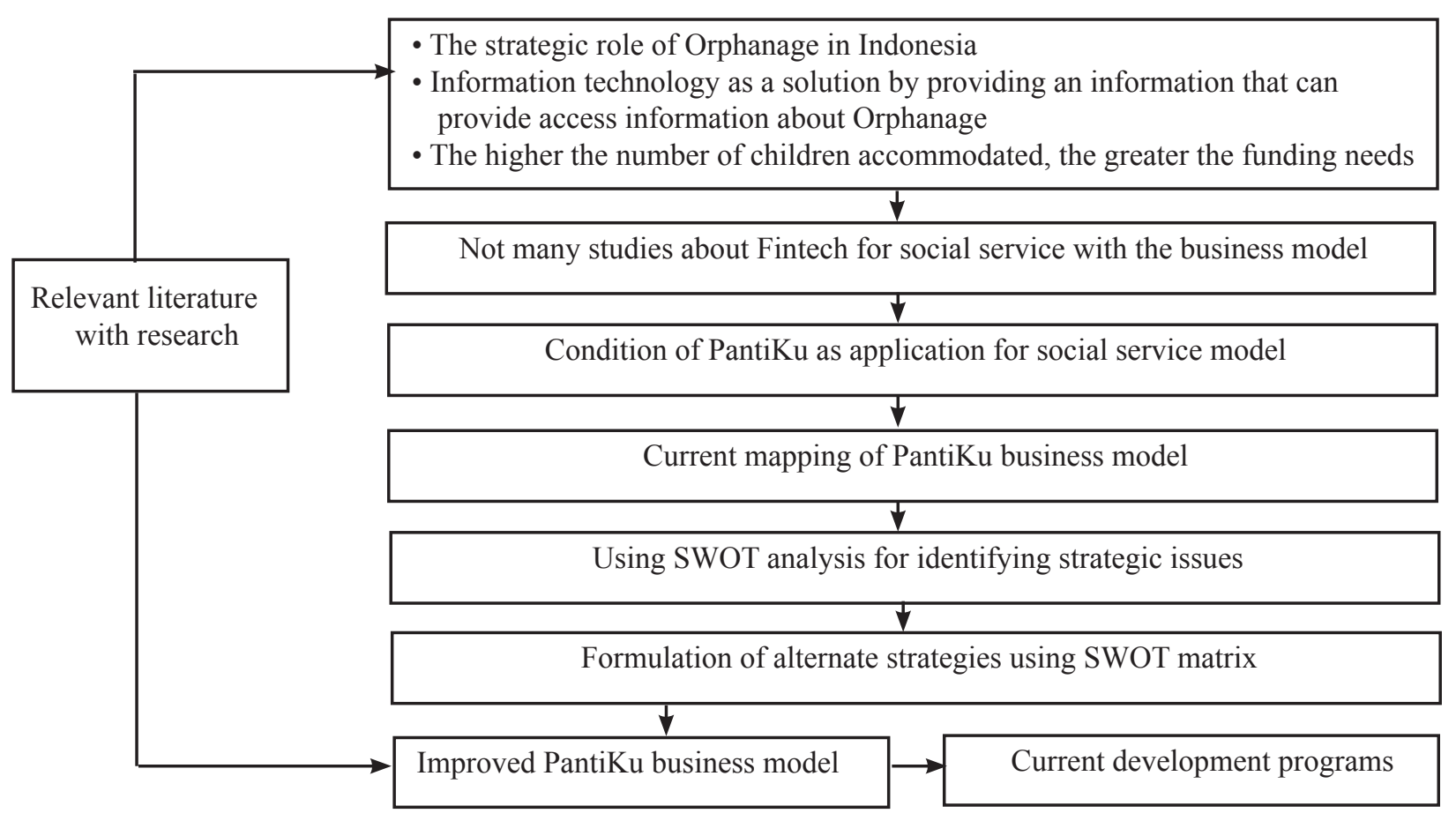

Figure 1. Research framework 


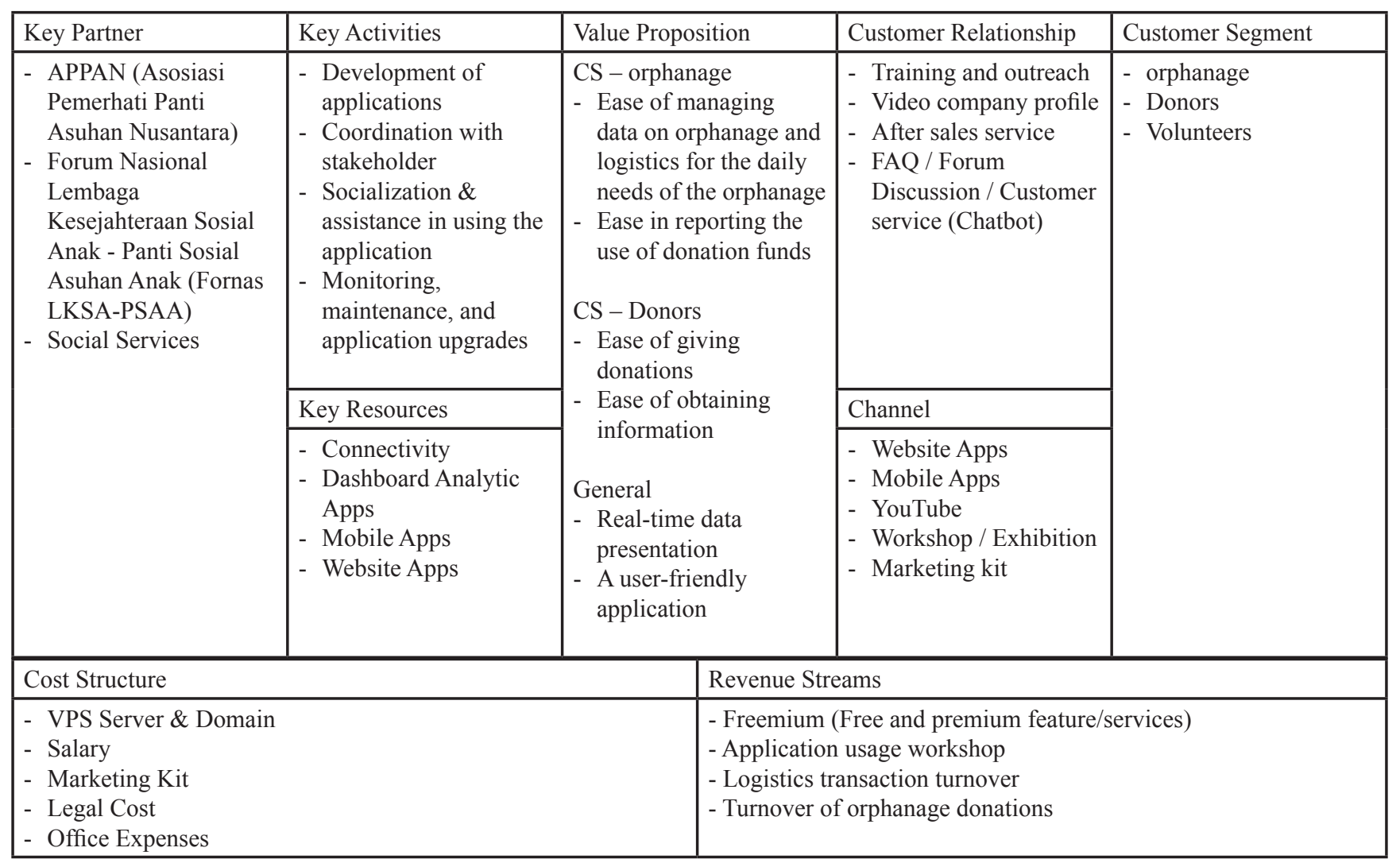

Figure 2. Business Model Canvas (BMC) PantiKu Apps

Customer Segments describes one or more customers that the company wants to serve through the given value proposition (Keane et al. 2018). User candidates of the PantiKu application are orphanages, donors, and volunteers. The orphanage as the main prospective user is a strategic party because of its role in implementing the PantiKu application, in several business process activities including data collection of foster children, nursing logistics and financial management of orphanages to create transparency.

Channels illustrate how a company communicates with its customer segments and reaches them (Nurhakim; Suparno; Nurrochmat, 2018). The PantiKu application uses marketing channels in the form of website apps, mobile apps, YouTube, exhibitions, and marketing media in the form of banners, banners, and posters.

Customer Relationship describes the types of relationships that companies build with specific market segments (Nurhakim; Suparno; Nurrochmat, 2018). Customer relationship processes are carried out through social media marketing, profile videos, aftersales services, and customer service using chatbots.
Revenue Stream is a revenue stream generated by companies from each customer segment (Nurhakim; Suparno; Nurrochmat, 2018). Sources of income that can be identified are Freemium packages (free and premium features/services), application usage workshops, logistics transaction turnover and turnover of orphanage donation transactions.

Key Resources describes the most critical assets owned by the PantiKu application so that a company goal can be achieved (Keane et al. 2018). Based on observations and interviews that have conducted, critical resources from the PantiKu application include 1) Connectivity, 2) Analytic Dashboard Applications, 3) Website Apps, 4) Mobile Apps.

PantiKu Key Activities consist of 1) Development of orphanage applications, 2) Coordination with orphanages, donors and associations, 3) Socialization \& mentoring of application use, 4) Monitoring, maintenance, and application upgrades. The main activities carried out are the development of applications along with the necessary features and accompanied by the process of coordination with orphanages, donors, and associations as stakeholders. Also, other activities 
are held as supporting operations in the form of socialization and assistance in the use of applications so that all stakeholders, especially orphanages understand and are accustomed to using the app along with the features included. The process of supervision, maintenance, and improvement of application features are also carried out regularly to ensure user comfort and the continued use of the application.

Key Partnership is a supporting partner for the PantiKu application business activities, which consists of 1) APPAN (Association of Observers of Archipelago orphanage), 2) National Forum for Child Welfare Institutions - Child Care Social Institutions (Fornas LKSA-PSAA), 3) Social Service.

Cost Structure is a representation in the form of money for all activities carried out on a business model (Osterwalder, 2004). Expenditures for the PantiKu application consist of two main components, namely the cost component for the application infrastructure (server, domain, and SSL certificate.) and the marketing/ implementation costs of the application (marketing kit, salary, legal cost).
Value Proposition (VP) is the main component to support the success of a business model (Metallo, Agrifoglio, Schiavone, \& Mueller, 2018). The value proposition carried on the PantiKu application is adjusted to Customer Segment (CS). For CS orphanages, the VP carried out consists of 1) Ease of management of data on orphanage and logistics for daily needs of the orphanage, 2) Ease in reporting the use of donation funds. For CS donors, the VP carried consists of 1) Ease of giving donations, 2) Ease of getting information about the need for donation to the home. As for General or overall CS, VP offered in the form of 1) Presentation of data in real-time (validity $\&$ accuracy of data), 2) Presentation of comprehensive data (complete data report and details), 3) Applications that are user-friendly.

\section{SWOT Analysis of PantiKu BMC}

After the process of identifying BMC elements done, the next step is to carry out a SWOT analysis for each BMC element. The results (Table 1) of the SWOT analysis are then used as the basis for the business model when the application is implemented and are expected to be the foundation for the sustainability of the form in the future.

Table 1. SWOT result analysis of PantiKu business model canvas

\begin{tabular}{|c|c|c|c|c|}
\hline Element & Strength & Weakness & Opportunity & Threat \\
\hline $\begin{array}{l}\text { Customer } \\
\text { Segments }\end{array}$ & $\begin{array}{l}\text { Has validated consumers } \\
\text { to several orphanages }\end{array}$ & $\begin{array}{l}\text { Information limitations } \\
\text { in giving donations, so } \\
\text { donations are often not on } \\
\text { target }\end{array}$ & $\begin{array}{l}\text { There are still some } \\
\text { segments that have } \\
\text { not well served like } \\
\text { volunteers } \\
\text { Community awareness } \\
\text { is increasing and } \\
\text { supported by increasing } \\
\text { economic capacity of } \\
\text { the community }\end{array}$ & $\begin{array}{l}\text { Consumptive lifestyle } \\
\text { and concerned with } \\
\text { personal interests }\end{array}$ \\
\hline $\begin{array}{l}\text { Value } \\
\text { Propositions }\end{array}$ & $\begin{array}{l}\text { Ease of access to nursing } \\
\text { home data needs through } \\
\text { application features }\end{array}$ & $\begin{array}{l}\text { Ease of access to nursing } \\
\text { home data needs through } \\
\text { application features }\end{array}$ & $\begin{array}{l}\text { Development of } \\
\text { Fintech features for } \\
\text { the Panti and IoT } \\
\text { donation and logistics } \\
\text { transactions in the } \\
\text { Panti logistics tracking }\end{array}$ & $\begin{array}{l}\text { The emergence of } \\
\text { other competitors by } \\
\text { offering applications } \\
\text { with similar functions }\end{array}$ \\
\hline Channels & $\begin{array}{l}\text { Dissemination of } \\
\text { application usage through } \\
\text { training programs }\end{array}$ & $\begin{array}{l}\text { Media socialization of the } \\
\text { use of apps is limited to } \\
\text { training programs }\end{array}$ & $\begin{array}{l}\text { Use of digital media } \\
\text { such as video, } \\
\text { e-learning, social } \\
\text { media, and other media }\end{array}$ & $\begin{array}{l}\text { Technology } \\
\text { acceptance is still } \\
\text { low }\end{array}$ \\
\hline $\begin{array}{l}\text { Customer } \\
\text { Relationship }\end{array}$ & $\begin{array}{l}\text { Have good relations and } \\
\text { have been running for a } \\
\text { long time with several } \\
\text { orphanages in application } \\
\text { development }\end{array}$ & $\begin{array}{l}\text { There is no budget } \\
\text { available for tours and } \\
\text { search activities to all the } \\
\text { institutions' locations }\end{array}$ & $\begin{array}{l}\text { Opportunities for grant } \\
\text { and incubation funds to } \\
\text { accelerate application } \\
\text { acceptance to several } \\
\text { Panti locations }\end{array}$ & $\begin{array}{l}\text { The characteristics of } \\
\text { the institution vary, } \\
\text { so it is necessary to } \\
\text { conduct a clustering }\end{array}$ \\
\hline
\end{tabular}


Table 1. SWOT result analysis of PantiKu business model canvas (Continued)

\begin{tabular}{|c|c|c|c|c|}
\hline Element & Strength & Weakness & Opportunity & Threat \\
\hline Key Partners & $\begin{array}{l}\text { Key Partners have } \\
\text { well identified, and } \\
\text { the existence of social } \\
\text { services in each region in } \\
\text { Indonesia }\end{array}$ & $\begin{array}{l}\text { The process of initiating } \\
\text { cooperation with the } \\
\text { Key Partner has not been } \\
\text { carried out }\end{array}$ & $\begin{array}{l}\text { The Key Partner will } \\
\text { welcome open social } \\
\text { innovation }\end{array}$ & $\begin{array}{l}\text { The low trust of the } \\
\text { Key Partner because } \\
\text { the application is a } \\
\text { new product }\end{array}$ \\
\hline Key Activities & $\begin{array}{l}\text { The main activities } \\
\text { identified have } \\
\text { been focused on the } \\
\text { development stage and } \\
\text { initial initiation }\end{array}$ & $\begin{array}{l}\text { The time of application } \\
\text { development is quite long } \\
\text { due to limited human } \\
\text { resources. }\end{array}$ & $\begin{array}{l}\text { Use of technology (data } \\
\text { mining - dashboard } \\
\text { data) that can increase } \\
\text { the added value and } \\
\text { efficiency of business } \\
\text { processes within the } \\
\text { organization. }\end{array}$ & $\begin{array}{l}\text { The application team } \\
\text { is not familiar with } \\
\text { the main activities of } \\
\text { the social field that } \\
\text { have identified }\end{array}$ \\
\hline Key Resources & $\begin{array}{l}\text { The readiness of a } \\
\text { suitable connectivity } \\
\text { device. } \\
\text { PT. Solusi Hijau already } \\
\text { has permission from BI } \\
\text { and OJK to market the } \\
\text { Fintech system. }\end{array}$ & $\begin{array}{l}\text { The limited number } \\
\text { human resources and } \\
\text { the majority of the } \\
\text { development team have } \\
\text { side jobs. }\end{array}$ & $\begin{array}{l}\text { Government- } \\
\text { provided competency } \\
\text { development program } \\
\text { (capacity building) }\end{array}$ & $\begin{array}{l}\text { The level of maturity } \\
\text { of the primary } \\
\text { resources owned by } \\
\text { competitors is better. }\end{array}$ \\
\hline Cost Structure & $\begin{array}{l}\text { The cost component } \\
\text { has well identified, } \\
\text { and efficiency and } \\
\text { optimization can be } \\
\text { done for the initial } \\
\text { implementation phase }\end{array}$ & $\begin{array}{l}\text { Parts of costs that have } \\
\text { not identified and the lack } \\
\text { of access to funds from } \\
\text { external parties }\end{array}$ & $\begin{array}{l}\text { There are several } \\
\text { assistance schemes } \\
\text { to subsidize the cost } \\
\text { structure }\end{array}$ & $\begin{array}{l}\text { Unexpected expenses } \\
\text { at the stage of } \\
\text { development and } \\
\text { implementation }\end{array}$ \\
\hline $\begin{array}{l}\text { Revenue } \\
\text { Streams }\end{array}$ & $\begin{array}{l}\text { Sources of income from } \\
\text { transaction turnover } \\
\text { (PantiPay transaction } \\
\text { fees), national and } \\
\text { international grant funds }\end{array}$ & $\begin{array}{l}\text { Low awareness about the } \\
\text { Fintech business model, } \\
\text { so it needs education } \\
\text { on business models that } \\
\text { use the latest technology } \\
\text { (Fintech, Internet of } \\
\text { Things, and Big Data } \\
\text { Analytics.) }\end{array}$ & $\begin{array}{l}\text { Social sector financial } \\
\text { transactions are mostly } \\
\text { in the form of cash } \\
\text { transactions, so they } \\
\text { have an excellent } \\
\text { opportunity to } \\
\text { transform into cashless } \\
\text { transactions }\end{array}$ & $\begin{array}{l}\text { Retention from Panti } \\
\text { on business models } \\
\text { and competitors who } \\
\text { use similar business } \\
\text { models }\end{array}$ \\
\hline
\end{tabular}

\section{Recommendations for Selecting a Business Strategy \\ Based on the results (Figure 3) of the nine elements identification and SWOT analysis of the canvas business model, some alternative strategies or programs formulated that could apply to the PantiKu application including:}

\section{Customer Segment}

S-O Strategy: Develop special features that can bring together volunteers with orphanages who need additional care workers, so that the community can donate in the form of voluntary energy.
Value Propositions

S-O Strategy: Develop IoT technology to facilitate the logistics process of Panti assistance and develop Fintech features in addition to being a media for donation transactions but also serves as a daily logistical, operational transaction for Panti.

\section{Channels}

W-O Strategy: Add tutorials for using applications in the form of interactive media such as e-learning while for the ST strategy: periodically extend training to orphanages to reduce the gap in technology use. 


\begin{tabular}{|c|c|c|}
\hline & \begin{tabular}{|l|} 
Strength (S) \\
1. PT. Solusi Hijau already has \\
permission from BI and OJK to \\
market the Fintech system \\
2. PT. Solusi Hijau has a several \\
networking with banking company. \\
3. Have a cooperation experience with \\
company and government. \\
4. Have a strong app developer team
\end{tabular} & $\begin{array}{l}\text { Weaknesses (W) } \\
\text { 1. Information limitations in giving } \\
\text { donations } \\
\text { 2. Parts of costs that have not } \\
\text { identified and the lack of access to } \\
\text { funds from external parties } \\
\text { 3. The limited number of human } \\
\text { resources and the majority of the } \\
\text { development team have side jobs } \\
\text { 4. Media socialization of the use of } \\
\text { apps is limited to training programs }\end{array}$ \\
\hline $\begin{array}{l}\text { Opportunities (O) } \\
\text { 1. The readiness of a suitable } \\
\text { connectivity device. } \\
\text { 2. Community awareness is } \\
\text { increasing and supported by } \\
\text { increasing economic capacity of the } \\
\text { community } \\
\text { 3. The use of digital media such as } \\
\text { video, e-learning, social media, and } \\
\text { other media } \\
\text { 4. Opportunities for grant and } \\
\text { incubation funds to accelerate } \\
\text { application acceptance. } \\
\text { 5. The use of technology data mining } \\
\text { - dashboard data } \\
\text { 6. Government-provided competency } \\
\text { development program (capacity } \\
\text { building) } \\
\text { 7. There are still some segments that } \\
\text { have not well served like volunteers }\end{array}$ & \begin{tabular}{|l} 
S-O Strategy \\
1. Develop special features that \\
can bring together volunteers \\
with orphanages who need \\
additional care workers, so that the \\
community can donate in the form \\
of voluntary energy. (S4, S3, O1, \\
O2, O7) \\
2. Develop IoT technology to \\
facilitate the logistics process of \\
orphanages assistance and develop \\
Fintech features in addition \\
to being a media for donation \\
transactions (S1, S4, O1, O6) \\
3. Utilizing and increasing the use \\
of digital financial instruments for \\
cash transactions by simplifying the \\
cashless transaction process. (S1, \\
S2, O1, O2, O3) \\
4. Budgeting cost of research (S3, S4, \\
O3, O5)
\end{tabular} & $\begin{array}{l}\text { W-O Strategy } \\
\text { 1. Utilizing opportunities for grants } \\
\text { and business incubation funds and } \\
\text { working with companies that have } \\
\text { CSR programs and startups (W2, } \\
\text { W3, O4, O5, O6) } \\
\text { 2. Establish relationships with the } \\
\text { government and companies with } \\
\text { CSR programs (W1, W2, O6, O3) } \\
\text { 3. Increase the use of data } \\
\text { management technology so that the } \\
\text { application development process } \\
\text { time becomes shorter and more } \\
\text { efficient. (W1, W3, O5, O2) } \\
\text { 4. Add tutorials in the form of } \\
\text { interactive media such as video, } \\
\text { e-learning and using social media } \\
\text { while for (W3, W4, O3, O6) }\end{array}$ \\
\hline $\begin{array}{l}\text { Threats }(\mathrm{T}) \\
\text { 1. The emergence of other } \\
\text { competitors by offering } \\
\text { applications with similar functions } \\
\text { 2. The level of maturity of the } \\
\text { primary resources owned by } \\
\text { competitors is better } \\
\text { 3. Unexpected expenses at the } \\
\text { stage of development and } \\
\text { implementation }\end{array}$ & \begin{tabular}{|l} 
S-T Strategy \\
1. Build trust in social services \\
by freely giving data mining \\
dashboards (T1, S4) \\
2. Evaluate expenses (unexpected \\
costs) periodically so that costs can \\
be minimized. (T3, S1, S2)
\end{tabular} & $\begin{array}{l}\text { W-T Strategy } \\
\text { Learning \& cooperate with other } \\
\text { competitors (collaboration) about } \\
\text { data sharing. (W1, W3, T1, T2) }\end{array}$ \\
\hline
\end{tabular}

Figure 3. PantiKu SWOT Matrix

\section{Customer Relationships}

W-O Strategy: Utilizing opportunities for grants and business incubation funds and working with companies that have CSR programs and startups, by forming special staff who are responsible for developing relations with the government and corporate CSR programs

\section{Revenue Streams}

S-O Strategy: Utilizing the use of digital financial instruments for cash transactions by simplifying the cashless transaction process. 


\section{Key Resources}

W-O Strategy: Adding staff government \& company relations development to establish relationships with the government and companies with CSR programs so that they get assistance to develop the application.

\section{Key Activities}

W-O Strategy: Increase the use of data management technology so that the application development process time becomes shorter and more efficient. S-T Strategy: Evaluate expenses (unexpected costs) periodically so that costs can be minimized.

\section{Key Partners}

S-T Strategy: Adding more strategic partner in social services by freely giving data mining dashboards while for W-T Strategy: Learning \& cooperate with other competitors about data sharing.

\section{Cost Structure (Strength - Threat)}

S-O Strategy: Creating budget for doing some research such as data mining research \& research for new features. This budget will be used as cost of research.

From the formulation of the SWOT strategy, four priority elements were chosen to immediately implemented as a business strategy, namely the approach of elements of customer segments, channels, key resources, and key activities (Figure 4). Besides, there are changes in the element, namely the addition of volunteers as a customer segment by developing special features that can bring together volunteers with orphanages who need additional foster workers or daily energy. Also, adding social media (Youtube) as an educational media for application usage on channel elements and improving the intensity of socialization and training for other orphanages in Indonesia. In addition to key resources elements, special staff need to be formed or recruited to build long-term relationships with the government and corporate CSR programs (Staff government \& company relations development). For key activities elements, a dashboard for internal application development team activities needed so that it can improve the efficiency of application development business processes and shorten application development time.

\section{Managerial Implications}

Some managerial implications that occur based on the priority of the development strategy of the BMC elements, include: increasing the time and costs needed to develop unique features on customer segments; needed a creative team to produce educational content for application users through available channels; increase the potential of aid funds for orphanages as the implications of the relationship that is woven with the government and companies in key resources components; the adaptation time needed by the team in the aspect of using the dashboard as a daily operational media for application development as part of key activities.

\section{CONCLUSIONS AND RECOMMENDATIONS}

\section{Conclusions}

The results of the study show that the current business model is not optimal. Therefore, changes were made in the form of adding entities or activities to the customer segment, channels, key resources, and key events as a form of improvement for the PantiKu business model. The additional strategies generated from SWOT matrix consists of 12 strategy formulas including (1) adding more strategic partner in social services, (2) learning \& cooperate with other competitors about data sharing, (3) develop dashboard of the internal activity, (4) evaluate expenses, (5) staff government \& company relation development, (6) develop IoT technology for logistics process, (7) develop Fintech feature for donation transaction, (8) developing relations with the government \& corporate CSR programs, (9) e-learning for tutorials, (10) Periodically extend training, (11) volunteers, (12) cost of research, (13) utilizing the use of digital financial instruments.

\section{Recommendations}

The suggestion for further research is that new research needed on the effectiveness of the implementation of business strategies that have been planned and implemented. 


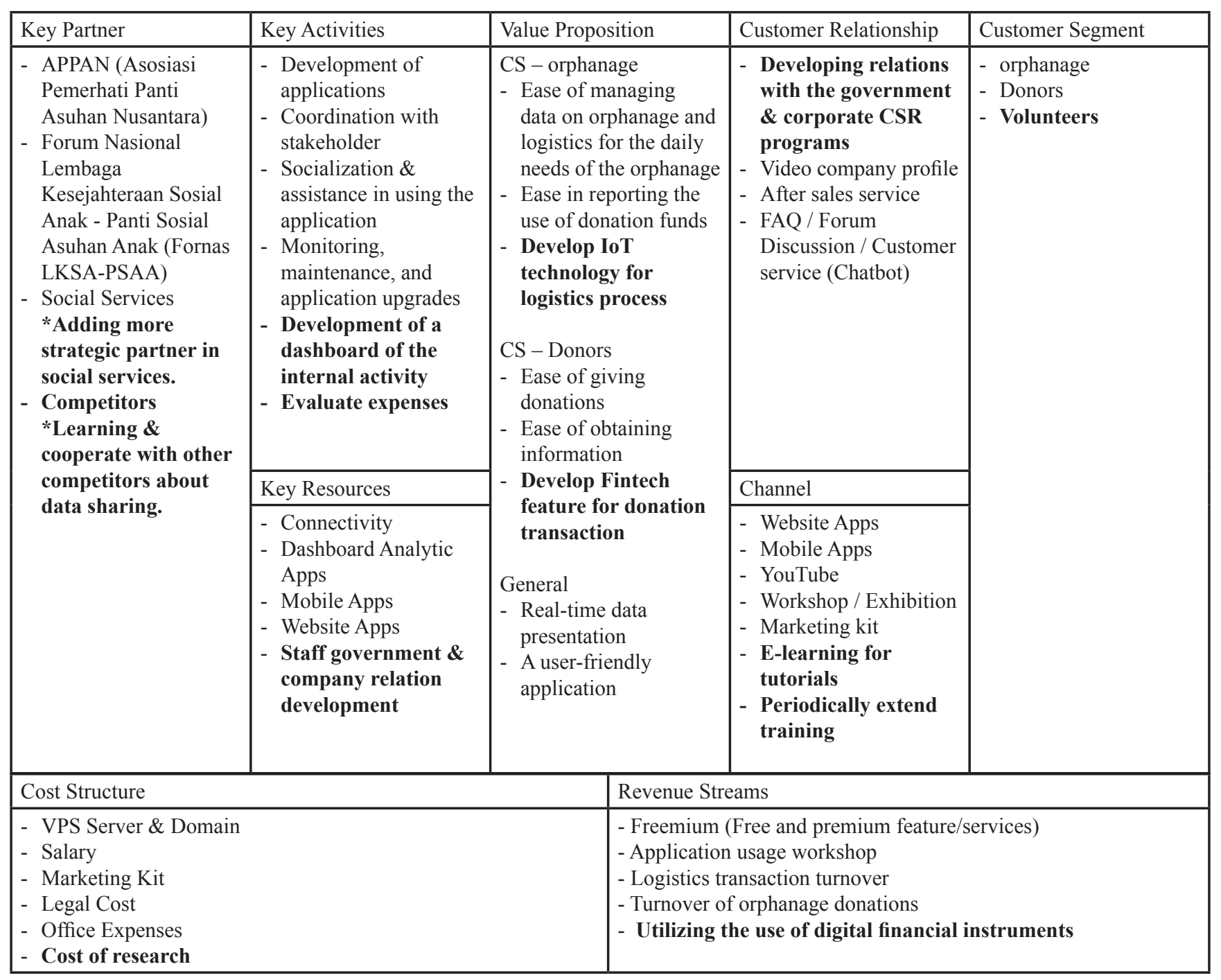

Figure 4. Improvement of BMC PantiKu Apps

\section{REFERENCES}

Ardela F. 2017. Teknologi Finansial: Tengok Dulu Perkembangan Fintech Di Indonesia!. https:// www.finansialku.com/perkembangan-Fintechdi-indonesia/

Bucherer E, Uckelmann D. 2011. Business Models for the Internet of Things. In Architecting the Internet of Things (pp. 253-277). Berlin, Heidelberg: Springer.https://doi.org/10.1007/978-3-64219157-2_10

Canestrino R, Ćwiklicki M, Di Nauta P, Magliocca,P. 2019. Creating social value through entrepreneurship: the social business model of La Paranza. Kybernetes 48(10): 2190-2216. https://doi.org/10.1108/K-03-2018-0135.

Cherif E, Grant D. 2014. Analysis of e-business models in real estate. Electronic Commerce Research 14(1): 25-50. https://doi.org/10.1007/s10660013-9126-z.
Dijkman RM, Sprenkels B, Peeters T, Janssen A. 2015. Business models for the Internet of Things. International Journal of Information Management 35(6): 672-678. https://doi. org/10.1016/j.ijinfomgt.2015.07.008

Díaz-Díaz R, Muñoz L, Pérez-González D. 2017. Business model analysis of public services operating in the smart city ecosystem: The case of SmartSantander. Future Generation Computer Systems 76: 198-214. https://doi.org/10.1016/j. future.2017.01.032.

Gabriel CA, Kirkwood J. 2016. Business models for model businesses: Lessons from renewable energy entrepreneurs in developing countries. Energy Policy 95: 336-349. https://doi. org/10.1016/j.enpol.2016.05.006.

Joyce A, Paquin RL. 2016. The triple layered business model canvas: A tool to design more sustainable business models. Journal of Cleaner Production 135: 1474-1486. https://doi.org/10.1016/j. 
jclepro.2016.06.067.

Ju J, Kim MS, Ahn JH. 2016. Prototyping business models for IoT service. Procedia Computer Science 91: 882-890. https://doi.org/10.1016/j. procs.2016.07.106

Kadir N. 2018. Analysis of entrepreneurship perception and business developmental strategy of silk in Wajo Regency, South Sulawesi, Indonesia. International Journal of Law and Management, 60(1), 102-113. https://doi.org/10.1108/IJLMA11-2016-0114.

Keane SF, Cormican KT, Sheahan JN. 2018. Comparing how entrepreneurs and managers represent the elements of the business model canvas. Journal of Business Venturing Insights 9: 65-74. https:// doi.org/10.1016/j.jbvi.2018.02.004.

Kuswandi. 2018. Mensos Dukung Pemulangan 67 Persen Anak Panti Asuhan ke Keluarganya.

León MC, et al. 2016. Designing a model of a digital ecosystem for healthcare and wellness using the business model canvas. Journal of Medical Systems 40(6): 144. https://doi.org/10.1007/ s10916-016-0488-3

Manafe D, Evani FS. 2017. 4,1 Juta Anak di Indonesia Telantar.

Martins HF, Mota JP, Marini C. 2019. Business models in the public domain: the public governance canvas. Cadernos EBAPE.BR, 17(1): 49-67. https://doi.org/10.1590/1679-395167893.

Metallo C, Agrifoglio R, Schiavone F, Mueller J. 2018. Understanding business model in the Internet of Things industry. Technological Forecasting and Social Change 136: 298-306. https://doi. org/10.1016/j.techfore.2018.01.020

Nguyen DTM, Nguyen TN, Le TL. 2019. Applying a mindfulness-based reliability strategy to the Internet of Things in healthcare - A business model in the Vietnamese market. Technological Forecasting and Social Change 140:54-68. https://doi.org/10.1016/j.techfore.2018.10.024.

Nurhakim AS, Suparno O, Nurrochmat DR. 2018. pengembangan model bisnis dan strategi pelayanan kesehatan XYZ. Jurnal Aplikasi Manajemen dan Bisnis 4(2): 251-260. https:// doi.org/10.17358/jabm.4.2.251.

Osterwalder A. 2004. The business model ontologyA proposition in a Design Science Approach. Business, Doctor, 1-169.

Prasetyo BB, Baga LM, Yuliati LN. 2018. Strategi pengembangan bisnis rhythm of empowerment dengan pendekatan model bisnis kanvas. Jurnal Aplikasi Manajemen dan Bisnis 4(2):296-307. https://doi.org/10.17358/jabm.4.2.296.

Sparviero S. 2019. The case for a socially oriented business model canvas: the social enterprise model canvas. Journalof SocialEntrepreneurship 10(2):1-20. https://doi.org/10.1080/19420676.2 018.1541011

Sun Y, Yan H, Lu C, Bie R, Thomas P. 2012. A holistic approach to visualizing business models for the internet of things. Communications in Mobile Computing 1(1): 1-4. https://doi. org/10.1186/2192-1121-1-4 